\title{
Assessment of the DNA Barcodes Characteristic of Phalaenopsis deliciosa based on matK, rbcL, and ITS
}

\author{
Nada Nisrina Maulidya, Siti Rohimah, Zakiyah Ramadany, Tri Ratnasari, Mukhamad Su'udi* \\ Department of Biology, Faculty of Mathematics and Natural Science, Universitas Jember \\ J1. Kalimantan No. 37 Krajan Timur, Jember, East Java, Indonesia. 68121 \\ *Email: msuudi52@gmail.com
}

\begin{abstract}
Indonesia has high biodiversity for plant species, including orchids with medicinal potential such as Phalaenopsis deliciosa. Generally, morphological characters, especially in flowers are used for orchids identification. However, when the plants are not in the flowering period, the identification becomes difficult. Therefore an alternative method, such as molecular identification (DNA barcoding) needs to be applied for the best solution. This research aims to identify and compare three markers ( $m a t K, r b c L$, ITS) for their function as potential barcodes for Phalaenopsis deliciosa. This study was conducted by DNA amplification using three different markers set. The data were analyzed using Bioedit, BLAST, and ClustalX. The result found that the identity level of $m a t K$, $r b c L$, and ITS to other orchids species was 99$98 \%, 98 \%$, and 94-96\%, respectively. Furthermore, matK and ITS showed high specificity for Phalaenopsis deliciosa, and are therefore recommended as the best molecular identification marker of genus Phalaenopsis.
\end{abstract}

Keywords: DNA barcoding; molecular identification; orchid; Phalaenopsis deliciosa

Article History: Received 30 March 2020; Received in revised form 15 May 2020; Accepted 26 September 2020; Available online 30 December 2020

How to Cite This Article: Maulidya NN, Rohimah S, Ramadany Z, Ratnasari T, Su'udi M. 2020. Assessment of the DNA Barcodes Characteristic of Phalaenopsis deliciosa based on matK, rbcL, and ITS. Biogenesis: Jurnal Ilmiah Biologi. vol 8(2): 138-144. doi: https://doi.org/10.24252/bio.v8i2.13278.

\section{INTRODUCTION}

Indonesia is a country with high biodiversity. The government declared through PERMENHUT No. 35 of 2007 (KLHK, 2007) that one of the potential biodiversity to be developed are ornamental plants, particularly orchids and those with medicinal properties (Hani et al., 2014; Wahyudiningsih \& Nion, 2017; Utami \& Hariyanto, 2019). Orchids belong to Orchidaceae family and has the most species-rich angiosperm when compared to other flowering plants group (Givnish et al., 2016; Fay, 2018; Tsiftsis et al., 2019). Furthermore, Indonesia has about 5000 species of orchids, about 1500 species have been identified (Schuiteman et al., 2010; Semiarti, 2012), and reports that some have the potential to be used as raw material for medicines (Hani et al., 2014; Teoh, 2016; Perwitasari et al., 2020). Some contain chemicals that are useful for therapeutic, such as glycerides, alkaloids, and others. When these plants are handled appropriately, they are useful as herbal medicines and have the potential to be used as a substitute for synthetic drugs. Herbal medicines are acceptably safe for health and have a dramatically fewer side effects (Taheri et al., 2011; Ekor, 2014; Moreira et al., 2014; Yao et al., 2016).

In general, morphological characteristics are used when identifying orchids and other plants. However, this approach sometimes meet obstacle since the vegetative characters of orchids are almost identical. Therefore, the existence of flowers as generative organs for identification is indispensable ( $\mathrm{Su}$ et al., 2013; Feng et al., 2015; Dirks-Mulder et al., 2017). For precision and also to support the conventional approach, the molecular markers through DNA barcoding used short fragments to identify the specimens is an alternative method (Jinbo et al., 2011; Li et al., 2011; Kim et al., 2014). DNA barcoding use marker selection that distinguish specific differences between species (Takamiya et al., 2011; Saddhe \& Kumar, 2018). The CBOL Plant Working Group (2009) suggests the use of two plastid genes, namely maturase-K (matK) and ribulose-1.5-bisphosphate carboxylase ( $r b c L)$ as the standard barcodes for plant DNA, and one potential nuclear ribosome DNA, namely the Internal Transcribed Spacer (ITS) region (Feng et al., 2015). Previously, the potential barcodes for Paphiopedilum and Thrixspermum 
orchids were investigated using in silico approaches (Rohimah et al., 2018; Sindiya et al., 2018). Therefore, this research aims to identify and compare three markers (matK, $r b c L$, ITS) for their function as potential barcodes for Phalaenopsis deliciosa. The core barcode for Phalaenopsis deliciosa thus can evaluate the tropical biodiversity especially in Indonesia.

\section{MATERIALS AND METHODS}

The samples were obtained from Kebon Agung orchids nursery located in Gebang district, Jember. They were morphologically identified using several identification books such as Orchids of Papua New Guinea (Millar, 1978), Lowland Orchids of Papua New Guinea (O'Byrne, 1994), Key to the genera of Orchidaceae of New Guinea (Schuiteman, 1995), and Flora Malesiana: Orchids of New Guinea (Schuiteman et al., 2010). For DNA extraction, the procedures were based on the standard protocol of genomic isolation kit (GeneAll Exgene ${ }^{\mathrm{TM}}$ Korea). Briefly, $0.1 \mathrm{~g}$ leaf sample was mixed with extraction buffer containing RNAse and crushed using mortar and pestle until homogenized. The mixture was centrifuged and the supernatant was recovered, which was then processed through filter column and dissolved with elution buffer in a total volume of $50 \mu \mathrm{L}$. The genomic DNA was then stored until used as a template in PCR amplification.

Subsequently, DNA amplification was performed using three different primer sets: 1$)$ matK_F (5'-CTTCTGGAGTCTTTCTTGAGC$\left.3^{\prime}\right)$ and matK_R (5' CCCAATACAGTACAAAA TTGAGC$\left.3^{\prime}\right)($ Khew \& Chia, 2011; Azofeifa-Bolaños et al., 2017), 2) rbcL_F (5'-
ATGTCACCACAAACAGAGACTAAAGC-3') and $\quad r b c L \_\mathrm{R} \quad\left(5^{\prime}-\mathrm{GTAAA}\right.$ ATCAAGTCCACCRCG-3')(Costion et al., 2011), and 3) ITS_F (5'GGCTCTCGCATCGATGAAGA-3') and ITS_R (5' TAGAATTCCCCGGTTCGCTCGCCGTTAC$3^{\prime}$ )(Sun et al., 1994; Martins et al., 2014). The total volume for PCR was $20 \mu \mathrm{L}$, consisting of DNA template, primer set, and PCR premix (AccuPower ${ }^{\circledR}$ PCR PreMix Bioneer Korea). The amplification reaction was performed in three steps include pre-denaturation at $95^{\circ} \mathrm{C}$ for $5 \mathrm{~min}, 30$ cycles of denaturation at $95^{\circ} \mathrm{C}$ for $30 \mathrm{~s}$, annealing at $53^{\circ} \mathrm{C}$ for $30 \mathrm{~s}$, and extension at $72^{\circ} \mathrm{C}$ for $1 \mathrm{~min} 20 \mathrm{~s}$, and the final extension at $72^{\circ} \mathrm{C}$ for $5 \mathrm{~min}$. After PCR, the product was loaded on $1.25 \%$ agarose gel electrophoresis containing $\mathrm{EtBr}$ and visualized under $\mathrm{UV}$ transilluminator.

The PCR product was then processed for sequencing using Macrogen Service Korea. Subsequently, the data were analyzed using several bioinformatics software such as Bioedit, BLAST, and ClustalX. The phylogenetic tree was constructed using MEGA5.05 (Zhai et al., 2013).

\section{RESULTS AND DISCUSSION}

Based on morphological characteristics, Phalaenopsis deliciosa has shown several characters such as growing epiphyte with a very short stem, monopodial, oblong-lanceolate leaves with undulate margins, and the flowers consist of two lateral sepals, one dorsal sepal, two petals and one labellum (Fig. 1). Furthermore, the flowers bloom sequentially to all directions. These characters are consistent with previous research on the morphology of Phalaenopsis deliciosa (Teoh, 2016). 


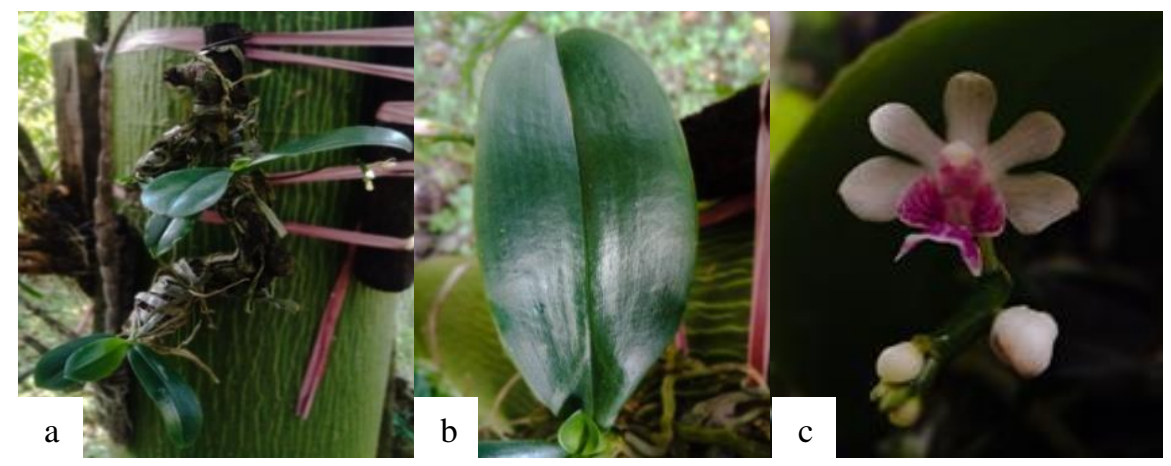

Fig. 1. The morphology of Phalaenopsis deliciosa in Kebon Agung orchids nursery: a. short stem; b. oblong-lanceolate leaves; c. flowers

In addition to the attractive flower character, Phalaenopsis deliciosa is used as a herbal ingredient, therefore, it is very important in orchid biodiversity (Ming, 2000; Huda et al., 2017). However, there are limited data related to genetic biodiversity for the DNA barcodes. As evidence, only matK is available in NCBI's GenBank for Phalaenopsis deliciosa (Hidayat et al., 2005). Furthermore, the samples were used to complete the existing data and its DNA barcodes were explored using three molecular markers. All primer sets for each marker was tested for amplification reaction through PCR. The results showed that the bands that appeared corresponded to the proposed sizes, which include $\pm 450 \mathrm{bp}, \pm 600 \mathrm{bp}$, and $\pm 500 \mathrm{bp}$ for $m a t K, r b c L$, and ITS, respectively (Fig. 2).

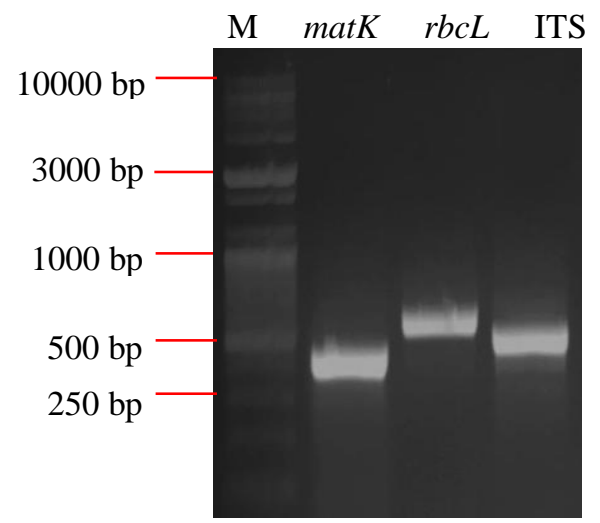

Fig. 2. The amplified PCR product of Phalaenopsis deliciosa using matK, $r b c L$ and ITS primer sets

Table 1. BLAST result of matK sequence from Phalaenopsis deliciosa

\begin{tabular}{llllll}
\hline Species & Accession Number & Per. Ident & Query Cover & E-value & Source \\
\hline Phalaenopsis deliciosa & KY966929.1 & $99.28 \%$ & $100 \%$ & 0.0 & China \\
Phalaenopsis deliciosa & KJ733590.1 & $99.28 \%$ & $100 \%$ & 0.0 & China \\
Phalaenopsis deliciosa & DQ091320.1 & $99.28 \%$ & $100 \%$ & 0.0 & USA \\
Phalaenopsis deliciosa & AB217749.1 & $99.03 \%$ & $100 \%$ & 0.0 & Japan \\
Phalaenopsis pulcherrima & MG459020.1 & $98.79 \%$ & $100 \%$ & 0.0 & China \\
Phalaenopsis pulcherrima & KJ733593.1 & $98.79 \%$ & $100 \%$ & 0.0 & China \\
Phalaenopsis pulcherrima & EF079282.1 & $98.79 \%$ & $100 \%$ & 0.0 & Poland \\
Phalaenopsis chibae & AB217748.1 & $98.79 \%$ & $100 \%$ & 0.0 & Japan \\
Doritis pulcherrima & AB217726.1 & $98.79 \%$ & $100 \%$ & 0.0 & Japan \\
Phalaenopsis zhejiangensis & KJ733594.1 & $98.55 \%$ & $100 \%$ & 0.0 & China \\
\hline
\end{tabular}

These results are consistent with related research that the proposed $m a t K$ used for barcoding is in the range of 450 bp (Khew \& Chia, 2011; Azofeifa-Bolaños et al., 2017). Relevant results were also illustrated in the amplification of PCR band using the $r b c L$ and ITS primer set (Fig. 2), which shows the appropriate range size and are also consistent with the previous reports (Costion et al., 2011; Martin et al., 2014).

The sequences from the three different primer sets were analyzed with BLAST for alignment, and MEGA5.05 for phylogenetic tree construction. Table 1 summarizes the BLAST results of matK sequence from the sample with the existing data in NCBI GenBank. 
The result showed that the matK sequence from samples have high similarity with those from Phalaenopsis deliciosa in China, USA, and Japan with an identity percentage greater than $99 \%$. This indicates that $m a t K$ is able to discriminate Phalaenopsis deliciosa down to the species level. The BLAST result is also in mutual agreement with the phylogenetic tree created (Fig. 3).

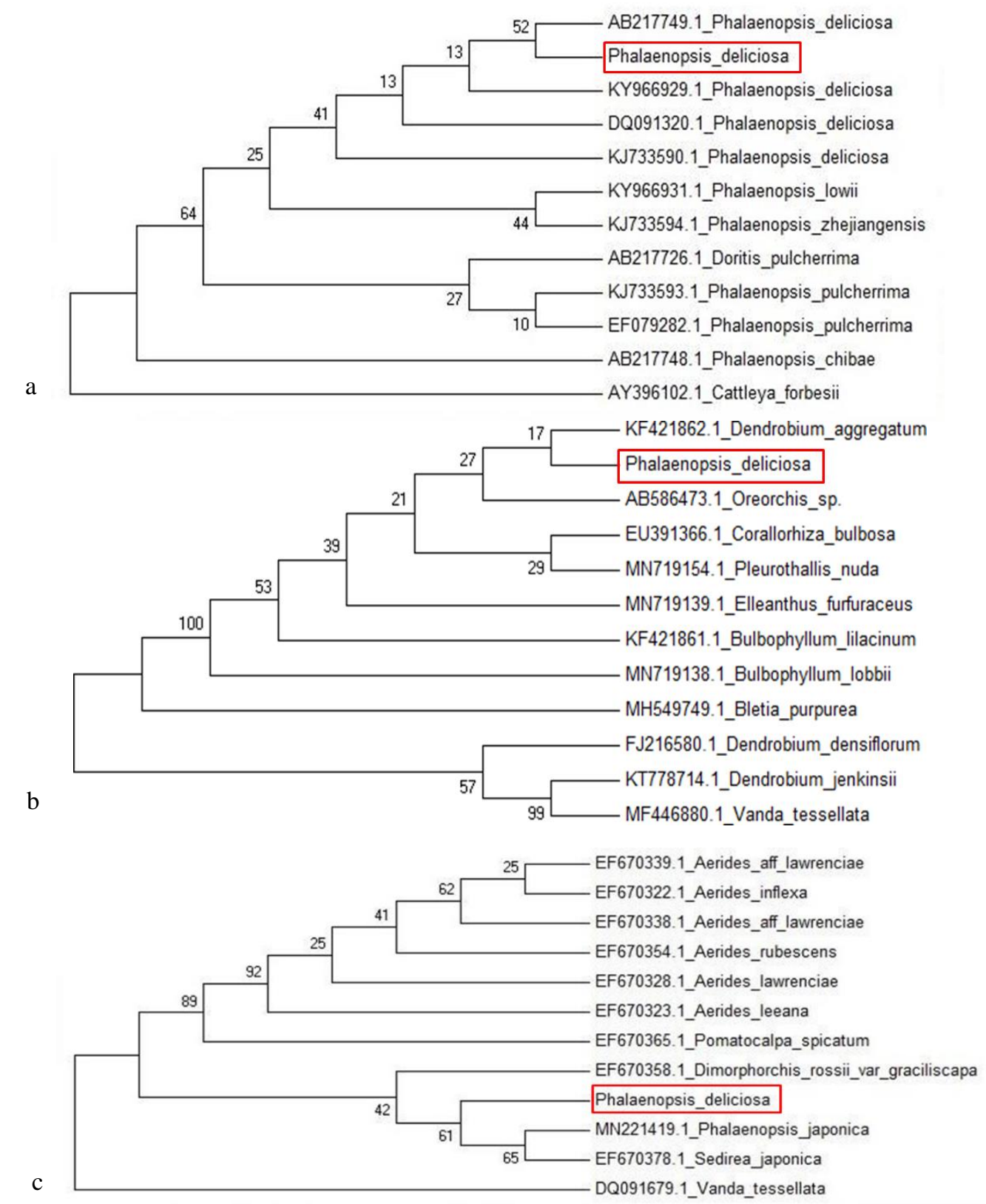

Fig. 3. Phylogenetic tree constructed from: a. matK sequences; b. rbcL sequences; c. ITS sequences of Phalaenopsis deliciosa by MEGA5.05 software

Contrary to $m a t K$, the sequence of $r b c L$ and ITS originating from Phalaenopsis deliciosa are not available in NCBI GenBank. Therefore, the sequences originating from this research are newly established. Table 2 and Table 3 illustrate the BLAST results of $r b c L$ and ITS sequences, from Phalaenopsis deliciosa compared to several orchids species available in GenBank. 
Table 2. BLAST result of $r b c L$ sequence from Phalaenopsis deliciosa

\begin{tabular}{llllll}
\hline Species & Accession Number & Per. Ident & Query Cover & E-value & Source \\
\hline Bletia purpurea & MH549749.1 & $98.41 \%$ & $99 \%$ & 0.0 & USA \\
Dendrobium aggregatum & KF421862.1 & $98.24 \%$ & $100 \%$ & 0.0 & Bangladesh \\
Corallorhiza bulbosa & EU391366.1 & $98.40 \%$ & $99 \%$ & 0.0 & USA \\
Elleanthus furfuraceus & MN719139.1 & $98.06 \%$ & $100 \%$ & 0.0 & Sweden \\
Bulbophyllum lobbii & MN719138.1 & $98.06 \%$ & $100 \%$ & 0.0 & Sweden \\
Bulbophyllum lilacinum & KF421861.1 & $98.06 \%$ & $100 \%$ & 0.0 & Bangladesh \\
Oreorchis sp. & AB586473.1 & $98.06 \%$ & $100 \%$ & 0.0 & Japan \\
Dendrobium jenkinsii & KT778714.1 & $98.22 \%$ & $99 \%$ & 0.0 & India \\
Dendrobium densiflorum & FJ216580.1 & $98.39 \%$ & $98 \%$ & 0.0 & China \\
Pleurothallis nuda & MN719154.1 & $98.22 \%$ & $99 \%$ & 0.0 & Swedia \\
\hline
\end{tabular}

Furthermore, $r b c L$ shows high identity (more than 98\%) with several orchids belonging to genus Bletia, Dendrobium, Corallorhiza, Elleanthus, Bulbophyllum, Oreorchis, and Pleurothallis. Meanwhile, the
ITS sequence shows a lower identity (94-96\%) with those of several orchids available in the NCBI database. The phylogenetic tree of both $r b c L$ and ITS, which shows mutual congruence are shown in Fig. 3b and Fig. 3c.

Table 3. BLAST result of ITS sequence from Phalaenopsis deliciosa

\begin{tabular}{llllll}
\hline Species & Accession Number & Per. Ident & Query Cover & E-value & Source \\
\hline Phalaenopsis japonica & MN221419.1 & $96.27 \%$ & $100 \%$ & 0.0 & South Korea \\
Sedirea japonica & EF670378.1 & $96.27 \%$ & $100 \%$ & 0.0 & Switzerland \\
Pomatocalpa spicatum & EF670365.1 & $95.25 \%$ & $100 \%$ & 0.0 & Switzerland \\
Dimorphorchis rossii & EF670358.1 & $95.23 \%$ & $100 \%$ & 0.0 & Switzerland \\
Aerides aff. lawrenceae & EF670339.1 & $95.04 \%$ & $100 \%$ & 0.0 & Switzerland \\
Aerides aff. lawrenceae & EF670338.1 & $95.04 \%$ & $100 \%$ & 0.0 & Switzerland \\
Aerides lawrenceae & EF670328.1 & $95.04 \%$ & $100 \%$ & 0.0 & Switzerland \\
Aerides leeana & EF670323.1 & $95.04 \%$ & $100 \%$ & 0.0 & Switzerland \\
Aerides inflexa & EF670322.1 & $95.04 \%$ & $100 \%$ & 0.0 & Switzerland \\
Aerides rubescens & EF670354.1 & $94.83 \%$ & $100 \%$ & 0.0 & Switzerland \\
\hline
\end{tabular}

The molecular markers used are from two different loci, $m a t K$, and $r b c L$ from plastid/chloroplast while ITS is derived from nuclei. This difference led to the strength and weakness of each marker. The study showed that the identity level of matK, $r b c L$, and ITS were 99, 98, and 94-96\%, respectively. Although all markers demonstrated the ability to discriminate against orchid species, the level of identity/similarity derived from sequence alignment has also become a crucial consideration. Furthermore, one of the best benchmarks of molecular markers in DNA barcoding is the existence of sequence variability, which indicates a high specificity level for identification. Consequently, the matK and ITS showed prominent character to be the recommended molecular marker for the identification of Phalaenopsis deliciosa.

\section{CONCLUSION}

The matK and ITS markers showed high specificity for Phalaenopsis deliciosa. Therefore, they are recommended as the best marker for the molecular identification of genus Phalaenopsis.

\section{ACKNOWLEDGEMENTS}

The authors thank to LPPM Universitas Jember for funding this research through Hibah Reworking 2020.

\section{REFERENCES}

Azofeifa-Bolaños JB, Gigant LR, Nicolás-García M, Pignal M, Tavares-González F, Hágsater E, Salazar-Chávez GA, Reyes-López D, ArchilaMorales FL, García-García JA, da Silva D, Allibert A, Solano-Campos F, Rodríguez-Jimenes G del C, Paniagua-Vásquez A, Besse P, Pérez-Silva A, Grisoni M. 2017. A new vanilla species from Costa Rica closely related to $V$. planifolia (orchidaceae). European Journal of Taxonomy. vol 284: 1-26. doi: http://dx.doi.org/10.5852/ejt.2017.284. 
CBOL Plant Working Group. 2009. A DNA barcode for land plants. Proceedings of the National Academy of Sciences of the United States of America. vol 106(31): 12794-12797. doi: https://doi.org/10.1073/pnas.0905845106.

Costion C, Ford A, Cross H, Crayn D, Harrington M, Lowe A. 2011. Plant DNA barcodes can accurately estimate species richness in poorly known floras. PLoS One. vol 6(11): 1-9. doi: https://doi.org/10.1371/journal.pone.0026841.

Dirks-Mulder A, Butôt R, van Schaik P, Wijnands JWPM, van den Berg R, Krol L, Doebar S, van Kooperen K, de Boer H, Kramer EM, Smets EF, Vos RA, Vrijdaghs A, Gravendeel B. 2017. Exploring the evolutionary origin of floral organs of Erycina pusilla, an emerging orchid model system. BMC Evolutionary Biology. vol 17(1): 1-18. doi: https://doi.org/10.1186/s12862-017-0938-7.

Ekor M. 2014. The growing use of herbal medicines: issues relating to adverse reactions and challenges in monitoring safety. Frontiers in Pharmacology. vol 4: 1-10. doi: https://doi.org/10.3389/fphar.2013.00177.

Fay MF. 2018. Orchid conservation: how can we meet the challenges in the twenty-first century? Botanical Studies. vol 59(1): 1-6. doi: https://doi.org/10.1186/s40529-018-0232-z.

Feng S, Jiang Y, Wang S, Jiang M, Chen Z, Ying Q, Wang H. 2015. Molecular identification of Dendrobium species (Orchidaceae) based on the DNA barcode ITS2 region and ITS application for phylogenetic study. International Journal of Molecular Sciences. vol 16(9): 21975-21988. doi: https://doi.org/10.3390/ijms160921975.

Givnish TJ, Spalink D, Ames M, Lyon SP, Hunter SJ, Zuluaga A, Doucette A, Caro GG, McDaniel J, Clements MA, Arroyo MTK, Endara L, Kriebel R, Williams NH, Cameron KM. 2016. Orchid historical biogeography, diversification, Antarctica and the paradox of orchid dispersal. Journal of Biogeography. vol 43(10): 1905-1916. doi: https://doi.org/10.1111/jbi.12854.

Hani A, Widyaningsih TS, Damayanti RU. 2014. Potensi dan pengembangan jenis-jenis tanaman anggrek dan obat-obatan di jalur wisata Loop-Trail Cikaniki-Citalahab Taman Nasional Gunung Halimun-Salak. Jurnal Ilmu Kehutanan. vol 8(1): 42-49. doi: https://doi.org/10.22146/jik.8574.

Hidayat T, Yukawa T, Ito M. 2005. Molecular phylogenetics of subtribe Aeridinae (Orchidaceae): Insights from plastid matK and nuclear ribosomal ITS sequences. Journal of Plant Research. vol 118: 271-284. doi: https://doi.org/10.1007/s10265-0050217-3.

Huda MK, Price A, Wilcock CC. 2017. Identification of medicinal orchids of Bangladesh: DNA barcoding vs. traditional taxonomy. The Journal of the Orchid Society of India. vol 31: 33-40.

Jinbo U, Kato T, Ito M. 2011. Current progress in DNA barcoding and future implications for entomology.
Entomological Science. vol 14(2): 107-124. doi: https://doi.org/10.1111/j.1479-8298.2011.00449.x.

Kementerian Lingkungan Hidup dan Kehutanan Republik Indonesia. 2007. Peraturan Menteri Kehutanan Nomor: P.35 / Menhut-II/2007. Jakarta: KLKH RI. https://www.menlhk.go.id/.

Kim HM, Oh SH, Bhandari GS, Kim CS, Park CW. 2014. DNA barcoding of Orchidaceae in Korea. Molecular Ecology Resources. vol 14(3): 499-507. doi: https://doi.org/10.1111/1755-0998.12207.

Khew GS-W, Chia TF. 2011. Parentage determination of Vanda Miss Joaquim (Orchidaceae) through two chloroplast genes rbcL and matK. AoB Plants. vol 2011: 1-12. doi: https://doi.org/10.1093/aobpla/plr018.

Li M, Cao H, But PPH, Shaw PC. 2011. Identification of herbal medicinal materials using DNA barcodes. Journal of Systematics and Evolution. vol 49(3): 271-283. doi: https://doi.org/10.1111/j.17596831.2011.00132.x.

Martins AC, Scherz MD, Renner SS. 2014. Several origins of floral oil in the Angelonieae, a southern hemisphere disjunct clade of Plantaginaceae. American Journal of Botany. vol 101(12): 2113 2120. doi: https://doi.org/10.3732/ajb.1400470.

Millar A. 1978. Orchids of Papua New Guinea. Canberra: ANU Press.

Ming BSY. 2000. The Catalogue of Medicinal Plants Resources in Taiwan (Chinese Edition). Kuala Lumpur: China Press. p. 120.

Moreira DDL, Teixeira SS, Monteiro MHD, De-Oliveira ACA, Paumgartten FJR. 2014. Traditional use and safety of herbal medicines. Revista Brasileira de Farmacognosia. vol 24(2): 248-257. doi: https://doi.org/10.1016/j.bjp.2014.03.006.

O'Byrne P. 1994. Lowland Orchids of Papua New Guinea. Singapore: National Parks Board Singapore.

Perwitasari DAG, Rohimah S, Ratnasari T, Sugiharto B, Su'udi M. 2020. DNA barcoding anggrek obat Dendrobium discolor Lindl. Tanimbar menggunakan gen $r b c L$ dan ITS. Buletin Penelitian Tanaman Rempah dan Obat. vol 31(1): 8-20. doi: http://dx.doi.org/10.21082/bullittro.v31n1.2020.820.

Rohimah S, Mukarramah L, Sindiya V, S VY, K GA, Su'udi M. 2018. Eksplorasi jenis dan potensi DNA barcode Thrixspermum secara in silico. Jurnal Biodjati. vol 3(2): 148-156. doi: https://doi.org/10.15575/biodjati.v3i2.3409.

Saddhe AA, Kumar K. 2018. DNA barcoding of plants: selection of core markers for taxonomic groups. Plant Science Today. vol 5(1): 9-13. doi: https://doi.org/10.14719/pst.2018.5.1.356.

Schuiteman A. 1995. Key to the genera of Orchidaceae of New Guinea. Flora Malesiana Bulletin. vol 11(6): 401-424.

Schuiteman A, Vermeulen JJ, de Vogel EF. 2010. Flora Malesiana: Orchids of New Guinea Vol. VI - Genus 
Bulbophyllum. Leiden: National Herbarium of the Netherlands.

Semiarti E. 2012. Kebutuhan inovasi dalam pengembangan industri anggrek yang berdaya saing dan berbasis sumber daya lokal. Prosiding Seminar Nasional Anggrek. June 21, 2012. Medan: Puslitbanghorti RI. ISBN: 978-979-8257-50-6. hal 21-28.

Sindiya V, Mukarramah L, Rohimah S, Perwitasari DAG, Su'udi M. 2018. Studi in silico potensi DNA barcode pada anggrek langka Paphiopedilum. Biosfer Jurnal Biologi dan Pendidikan Biologi. vol 3(1): 2549-0486. doi: http://dx.doi.org/10.23969/biosfer.v3i1.1250.

Su CL, Chen WC, Lee AY, Chen CY, Chang YCA, Chao YT, Shih MC. 2013. A modified ABCDE model of flowering in orchids based on gene expression profiling studies of the moth orchid Phalaenopsis aphrodite. PLoS One. vol 8(11): 1-14. doi: https://doi.org/10.1371/journal.pone.0080462.

Sun Y, Skinner DZ, Liang GH, Hulbert SH. 1994. Phylogenetic analysis of Sorghum and related taxa using internal transcribed spacers of nuclear ribosomal DNA. Theoretical and Applied Genetics. vol 89(1): 26-32. doi: https://doi.org/10.1007/BF00226978.

Taheri JB, Azimi S, Rafieian N, Zanjani HA. 2011. Herbs in dentistry. International Dental Journal. vol 61(6): 287-296. doi: https://doi.org/10.1111/j.1875-595X.2011.00064.X.

Takamiya T, Wongsawad P, Tajima N, Shioda N, Lu JF, Wen CL, Wu JB, Handa T, Ijima H, Kitanaka S, Yukawa T. 2011. Identification of Dendrobium species used for herbal medicines based on ribosomal DNA Internal transcribed spacer sequence. Biological and Pharmaceutical Bulletin. vol 34(5): 779-782. doi: https://doi.org/10.1248/bpb.34.779.

Teoh ES. 2016. Medicinal orchids of Asia. Switzerland: Springer International Publishing. p. 583. doi: https://doi.org/10.1007/978-3-319-24274-3.

Tsiftsis S, Štípková Z, Kindlmann P. 2019. Role of way of life, latitude, elevation and climate on the richness and distribution of orchid species. Biodiversity and Conservation. vol 28(1): 75-96. doi: https://doi.org/10.1007/s10531-018-1637-4.

Utami ESW, Hariyanto S. 2019. In vitro seed germination and seedling development of a rare Indonesian native orchid Phalaenopsis amboinensis J.J.Sm. Scientifica. vol 2019: 1-7. doi: https://doi.org/10.1155/2019/8105138.

Wahyudiningsih TS, Nion YA. 2017. Pemanfaatan anggrek spesies Kalimantan Tengah berbasis kearifan lokal yang berpotensi sebagai bahan obat herbal. Jurnal Biodjati. vol 2(2): 149-158. doi: http://doi.org/10.15575/biodjati.v2i2.1570.

Yao H, Qiao YJ, Zhao YL, Tao XF, Xu LN, Yin LH, Qi Y, Peng JY. 2016. Herbal medicines and nonalcoholic fatty liver disease. World Journal of Gastroenterology. vol 22(30): 6890-6905. doi: https://dx.doi.org/10.3748\%2Fwjg.v22.i30.6890.

Zhai JW, Zhang GQ, Chen LJ, Xiao XJ, Liu KW, Tsai WC, Hsiao YY, Tian HZ, Zhu JQ, Wang MN, Wang FG, Xing FW, Liu ZJ. 2013. A new orchid genus, Danxiaorchis, and phylogenetic analysis of the tribe Calypsoeae. PloS One. vol 8(4): 1-10. doi: https://doi.org/10.1371/journal.pone.0060371. 